\title{
HERITABILITY AND CONNECTIONS OF SOW FERTILITY TRAITS
}

\author{
M. Popovac ${ }^{1}$, D. Radojković ${ }^{1}$, M. Petrović ${ }^{1}$, M. Mijatović ${ }^{1}$, M. Gogić ${ }^{2}$, \\ D. Stanojević ${ }^{1}$, N. Stanišić ${ }^{2}$
}

${ }^{1}$ Faculty of Agriculture, University of Belgrade, Nemanjina 6, 11080 Belgrade-Zemun, Republic of Serbia

${ }^{2}$ Institute for Animal Husbandry, Autoput 16, 11080, Belgrade-Zemun, Republic of Serbia Corresponding author: mlp@agrif.bg.ac.rs

Original scientific paper

Abstract: Purpose of this paper was to determine fertility traits heritability coefficients of the sows (number of live born, total number of born, stillborn and reared piglets in the litter) and interconnections between these traits. Heritability coefficients were low and averaged in interval from $\mathrm{h}^{2}=0,056$ for number of reared piglets in litter to $\mathrm{h}^{2}=0,142$ for total number of born piglets in litter, which is in accordance with heritability values for reproductive traits. Genetic interconnections of these traits had wide variation interval and averaged from $r=$ 0,221 between number of still born and reared piglets in litter to $r=0,947$ between total number of born and number of live born piglets in litter. Coefficients of phenotype correlation varied in interval from $r=-0,162$ between number of still born and number of live born piglets in litter to $r=0,909$ between total number of born and number of live born piglets in litter.

Key words: sow, heritability, genetic and phenotype connection

\section{Introduction}

Parental genetic influence at daughter fertility is relatively low if we take that reproductive traits are highly conditioned by the environment factors. However, even beside that if we were to make genetic improvement it is needed to choose those parents that have best results in reproduction. As reproductive boars have greater number of offspring it is needed to have strict selection, greater number of offspring (daughters) furthermore gives opportunity to get more accurate results at progeny testing of same boars.

Greater number of research that refer to size of the litter in different population of pigs showed that heritability coefficients and repetitiveness are low $(10-15 \%)$, and that variation coefficient were relatively high $(25 \%)$. 
Most frequently evaluated genetic trait of pigs is the number of live born piglets in the litter. According to Bereskin (1984) value of the heritability coefficient for this trait is 0,05 while Skorupski et al., (1996) determined the value of 0,19 . Next to the number of live born piglets in litter, very frequently traits like total number of born piglets, number of stillborn piglets and number of reared piglets in liter were researched, which was done in this research too.

After determining the heritability coefficient for fertility traits it was necessary to determine correlation between researched traits, which is shown by phenotype and genetic correlation coefficients. Absolute values and sign in front of these coefficients point how much and how these traits are interconnected. Therefore knowing about values of these coefficients gives the possibility to alter certain traits in such manner that values of other traits are not affected.

Value for phenotype correlation coefficient which was determined by Popov et al., (2003) between number of live born and still born piglets in the litter was 0,218 . Relatively low value of this coefficient shows weak correlation between these two traits, much larger coefficient was determined for genetic correlation coefficient 0,803 between these two traits. The high value of genetic correlation coefficient was also determined by Roehe and Kennedy (1995). This shows that with value increase of one trait the value of other trait increases too, and vice versa.

\section{Material and methods}

A criterion on which calculation of heritability and correlation coefficient was based was that fathers of analyzed sows have 10 and more daughters in the researched group of sows. Based on this criterion 54 boars and their 1318 daughters which had 4489 litters were taken. Fertility traits for which heritability and their phenotype and genetic correlation was calculated were: total number of born piglets in litter (TNBPL), number of live born piglets in litter (NLBPL), number of still born piglets in litter (NSBPL) and number of reared piglets in litter (NRPL).

Starting analysis has rounded descriptive statistic data rendering where arithmetic mean and indicators of variation (variation coefficient, standard deviation and variation interval) were calculated. Mathematic-statistical data processing was done by applying the mix model, method of least squares and application of program package by Harvey (1990) within which using the method of interclass correlation of half-sisters heritability was calculated as well as genetic and phenotype coefficients. In the variance analysis model based on which heritability for specific traits was calculated, beside the sow father following factors were included: farm, genotype, furrowing year, furrowing season, furrowing order, number of teats and age at first furrowing. For these factors it was determined that they have significant statistic influence on researched traits, 
however those factors will not be discussed further. In this way more accurate heritability coefficient was determined and in certain measure surrounding variability influence was brought to minimum. Presented results were calculated with help of following mix model:

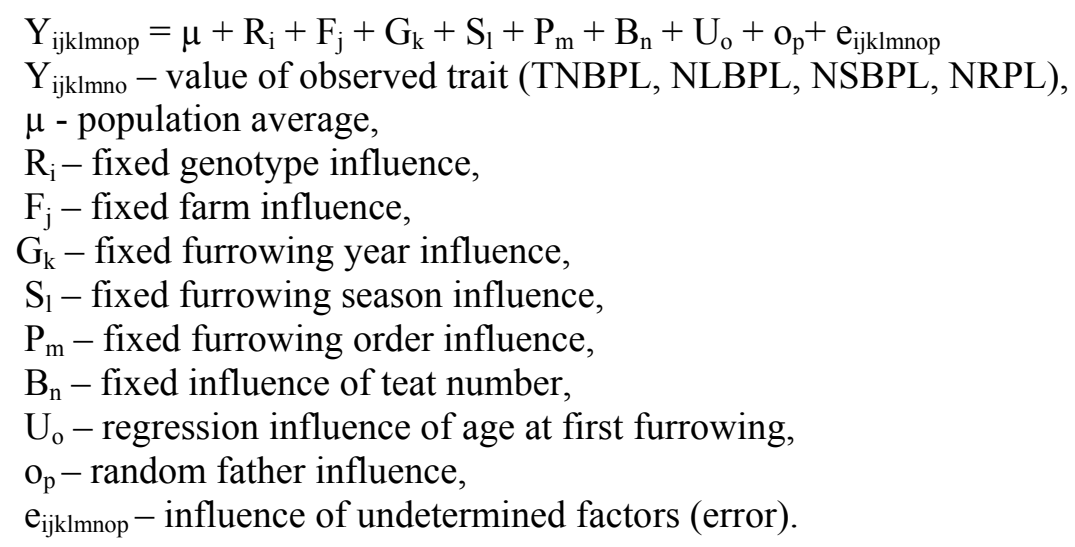

\section{Research results and discussion}

Heritability of researched traits in the Table 1 . Values of heritability coefficients for traits: total number of born (TNBPL), live-born (NLBPL), stillborn (NSBPL) and number of reared (NRPL) piglets in the litter of researched sows.

Table 1. Heritability values determined by analysis

\begin{tabular}{|c|c|}
\hline Trait & Heritability and heritability standard error \\
\hline TNBPL & $0,142 \pm 0,034$ \\
\hline NLBPL & $0,123 \pm 0,031$ \\
\hline NSBPL & $0,083 \pm 0,024$ \\
\hline NRPL & $0,056 \pm 0,020$ \\
\hline
\end{tabular}

Results show that values of heritability are low and that they vary in the interval from 0,056 to 0,142 . Highest heritability value $h^{2}=0,142$ is noted for total number of born piglets in litter. Notably more important trait like number of live born piglets has slightly lower value of $\mathrm{h}^{2}=0,123$, which represents strong influence of non genetic factors on this trait. Heritability coefficient for NLBPL in this research is somewhere in between the varying interval for this coefficient $(0,05-$ 0,19) which was determined by Skorupski et al., (1996) and Bereskin (1984) in their research.

Opposite to these traits number of reared piglets in litter has the lowest value of $\mathrm{h}^{2}=0,056$ because of the strong influence of the surrounding at the number of reared piglets (handling with piglets, diet, care and housing of sow and piglets). 
Roehe and Kennedy (1995) have determined almost the same value for this trait in their research.

When we look at the number of stillborn piglets in the litter of researched sows it has been determined that, that value is influenced with $\mathrm{h}^{2}=0,083$ by genetic factors. Of course it would have been ideal if number of stillborn piglets were to be equal to zero, however as that is not possible the goal is to keep that number as low as possible. As it is quoted by Popov et al., (2003) heritability for number of still born piglets is 0,017 which is almost five times lower value compared to value that was determined in this analysis. Furthermore according to Roehe and Kennedy (1995) heritability value is 0,06, while Southwood and Kennedy (1990) quote that heritability for this trait is 0,13 . Determined value for NSBPL heritability is within limits of values that were determined by the last two groups of researchers. All this is pointing that number of stillborn piglets is significantly more influenced by other factors than it is influenced by heritability.

Correlation between the researched fertility traits. In order to see the correlation and in order to interpret it in a best way genetic and phenotype correlation coefficients will serve as best example. Correlation coefficients between researched traits show inter-correlation between the same. Correlation coefficients for fertility traits of researched sows are shown in Table 2.

Table 2. Genetic correlation coefficients for fertility traits and their significance ${ }^{1)}$

\begin{tabular}{|c|c|c|c|}
\hline Trait & NLBPL & NSBPL & NRPL \\
\hline TNBPL & $0,947^{* *}$ & $0,429^{* * *}$ & $0,619^{* *}$ \\
\hline NLBPL & - & $0,117^{* *}$ & $0,759^{* *}$ \\
\hline NSBPL & - & - & $-0,221^{* *}$ \\
\hline
\end{tabular}

High value of genetic correlation coefficient $(\mathrm{r}=0,947$, total correlation) between total number of born and number of live born piglets is understandable and it shows that by selection for higher number of live born piglets in litter there is increase of total number of born piglets. High value for genetic correlation coefficient 0,947 between total number of born and number of live born piglets in litter was also determined by Roehe and Kennedy (1995).

Genetic correlation coefficient between NLBPL and NSBPL was 0,117 which shows low genetic correlation compared to correlation $(0,803)$ that was determined by Popov et al., (2003).

In the Table 2. negative value for genetic correlation coefficients is also shown, which points that during selection for one trait, value of other trait decreases and vice versa. Even though a very low value $-0,221$ (very low correlation), between number of reared and number of still born piglets, it shows that generally in researched litters with higher number of reared piglets was less stillborn piglets. 
However, low absolute values for genetic correlation coefficient give the possibility for improvement of one trait with selection without significantly violating the value of the other trait.

Phenotype correlation coefficients show more objective correlation influence because it is not possible to clearly separate surrounding environment and genetic factors influence on trait. Phenotype correlation coefficients besides genetic factors include the environment factors.

Table 3. Phenotype correlation coefficients for fertility traits ${ }^{1)}$

\begin{tabular}{|c|c|c|c|}
\hline Trait & NLBPL & NSBPL & NRPL \\
\hline TNBPL & $0,909^{* *}$ & $0,264^{* *}$ & $0,227^{* *}$ \\
\hline NLBPL & - & $-0,162^{* *}$ & $0,281^{* *}$ \\
\hline NSBPL & - & - & $-0,133^{* *}$ \\
\hline
\end{tabular}

1) Correlation coefficient for 5 and $1 \%$ certainty (d.f. $=1000)$ is 0,062 and 0,081 .

In the Table 3. high value for phenotype correlation coefficient is shown $(\mathrm{r}=0,909$, total correlation $)$ between total number of born piglets and number of live born piglets, as it was for genetic correlation which shows that in production environment with value increase for one trait, the value of other trait is also increased. Result is almost identical to the result determined by Radojković et al. ,(2005).

Number of reared and totally born piglets in litter in this research has low coefficient of phenotype correlation $(\mathrm{r}=0,227$, very low correlation). Gajić and Radivojević (1980) have also in their research determined lower value for this coefficient 0,265, while Lui et al., (1982) have determined high correlation for this trait and the coefficient was 0,930 .

Table 3. also shows negative values for correlation coefficients which point that with increase of value for one trait, the value of other trait is decreasing. Negative value for phenotype correlation coefficient $-0,162$ (very low correlation) was determined between number of live born piglets and number of stillborn piglets in litter. Results are not in agreement with results determined by Popov et al., (2003) who have determined the positive value $(0,218)$ of phenotype correlation coefficient for these two traits.

It has to be emphasized that all correlation coefficients are statistically significant. Level and strength of correlation is determined based on values that were given in the tables by Latinović (1996).

\section{Conclusion}

Heritability coefficients were in the interval between 0,056 for NRPL and up to 0,142 for TNBPL. These low values of heritability are connected to reproductive traits and they show how much surrounding environment factors significantly influence the fertility of the pigs. Moreover, these low values of 
heritability for fertility traits emphasize the need for bettering the surrounding environment condition which has strong influence on researched traits.

All genetic and phenotype correlation coefficients were statistically significant. The lowest genetic correlation $(0,117)$ was between NLBPL and NSBPL, while almost total genetic correlation $(0,947)$ was determined between NLBPL and TNBPL.

Determined heritability and correlation coefficient values show that there is possibility for selection and improvement of significant reproductive traits, which should result in genetic progress for researched pig population.

\title{
Acknowledgements
}

Research was financed by the Ministry of Education Science, and Technological Development, Republic of Serbia, project TR 31081.

\section{Naslednost i povezanost osobina plodnosti krmača}

\author{
M. Popovac, D. Radojković, M. Petrović, M. Mijatović, M. Gogić, D. Stanojević, \\ N. Stanišić
}

Rezime

Cilj rada bio je da se utvrde koeficijenti naslednosti osobina plodnosti krmača (broj živorođene, ukupno rođene, mrtvorođene i odgajene prasadi u leglu) i međusobna povezanost ovih osobina. Koeficijenti heritabiliteta su bili niski i kretali su se $\mathrm{u}$ intervalu od $\mathrm{h}^{2}=0,056$ za broj odgajene prasadi u leglu do $\mathrm{h}^{2}=0,142$ za broj ukupno rođene prasadi u leglu, što je u skladu sa vrednostima heritabiliteta za reproduktivne osobine. Genetska povezanost ovih osobina imala je širok interval variranja i kretala se od $r=-0,221$ između broja mrtvorođene i broja odgajene prasadi u leglu, do $\mathrm{r}=0,947$ između broja ukupno rođene i broja živorođene prasadi u leglu. Koeficijenti fenotipske korelacije kretali su se u intervalu od $r=-0,162$ između broja mrtvorođene $i$ broja živorođene prasadi $u$ leglu, do $\mathrm{r}=0,909$ između broja ukupno rođene i broja živorođene prasadi u leglu.

\section{References}

BERESKIN B. (1984): A genetic analysis of sow productivity traits. Journal of Animal Science, 59, 5, 1149-1163.

GAJIĆ I., RADIVOJEVIĆ R. (1980): Značaj i veličina genetskih promena iz direktne i indirektne selekcije svinja. Savremena poljoprivreda, 28, 3-4, 111-121. 
HARVEY R.W. (1990): User's guide for LSMLMW and MIXMDL. Ver. PC-2, 1-91. LATINOVIĆ D. (1996): Populaciona genetika i oplemenjivanje domaćih životinja. Praktikum, Beograd, 1-173.

LUI J.F., GIANNONI M.A., BANZATTO D.A., CARREGAL R.D. (1982): Razao sexual, taxa mortalidade, numero medio de tetas e correlacoes lineares entre caracteristicas de leitegades das racas Duroc E Landrace. Revista da Sociedade Brasileira de Zootehnica, 11, 1, 1-13.

POPOV R., RADOVIĆ I., TRIFUNOVIĆ S., TEODOROVIĆ M., PETROVIĆ M. (2003): Fenotipska ispoljenost, varijabilnost i naslednost osobina plodnosti svinjabroj mrtvorođene prasadi u leglu. Savremena poljoprivreda, 52, 3-4, 297-302.

RADOJKOVIĆ D., PETROVIĆ M., MIJATOVIĆ M., RADOVIĆ I. (2005): Fenotipska i genetska povezanost osobina plodnosti plotkinja švedskog landrasa. Biotechnology in Animal Husbandry, 21, 3-4, 79-88.

ROEHE R., KENNEDY B. W. (1995): Estimation of genetic parametars for litter size in Canadian Yorkshire and Landrace swine with each party of farrowing treated as a different trait. Journal of Animal Science, 73, 10, 2959-70.

SKORUPSKI M. T., GARRICK D. J., BLAIR H. T. (1996): Estimates of direct and maternal genetic parameters for production and reproduction traits in tree breeds of pigs. New Zeland Journal of Agriculture Research, 39, 3, 387-395.

SOUTHWOOD O. I., KENNEDY B. W. (1990): Estimation of direct and maternal genetic variance for litter size in Canadian Yorkshire and Landrace swine using an animal model. Journal of Animal Science, 68, 7, 1841-1847. 